\title{
ДО ТЕМИ ПРО РОЛЬ МЕДСЕСТРИ ЗА УМОВ СТВОРЕННЯ ТЕРИТОРІАЛЬНИХ ТА ГОСПІТАЛЬНИХ ОКРУГІВ ЧЕРЕЗ ПРИЗМУ РЕФОРМИ ОХОРОНИ ЗДОРОВ'Я
}

\author{
О. Н. Литвинова, Р. А. Демус \\ ДВНЗ «Тернопільський державний медичний університет \\ імені І. Я. Горбачевського МОЗ Украӥни" \\ Калуська ЦРЛ Департаменту охорони здоров'я Івано-Франківської ОДА
}

У статті проаналізовано правову базу створення госпітальних округів та перспективи вивчення розвитку медсестринства в ракурсі цієї реформи.

\section{TO THE THEME ABOUT THE ROLE OF A NURSE IN THE CONDITIONS OF THE CREATION OF TERRITORIAL AND SOCIAL DISTRICTS THROUGH THE PRISM OF HEALTH REFORMS}

\author{
O. N. Lytvynova, R. A. Demus \\ I. Horbachevsky Ternopil State Medical University \\ Kalush Central District Hospital of the Department of Health Care \\ of Ivano-Frankivsk Regional State Administration
}

The article analyzes the legal basis for the establishment of hospital districts and the prospects for studying the development of nursing in the perspective of this reform.

Вступ. Сьогодні, коли система охорони здоров'я перебуває в стані реформування галузі, питання ролі та місця медсестри в новій структурі системи охорони здоров'я $\epsilon$ особливо актуальним. Проекти більшості законодавчих актів із питань реформи передбачають оптимізацію галузі, що почасти тягне за собою скорочення як кадрів, так і потужностей закладів охорони здоров'я. Політику збереження та перепрофілізації кадрів середнього медичного персоналу поки що не розглядають, окрім фельдшерів швидкої допомоги, яких перепрофільовують у парамедиків. Мета роботи: виявити роль та місце медсестри у новій системі через призму аналізу проекту реформи системи охорони здоров'я, зокрема у світлі формування госпітальних округів.

Основна частина. Концепція госпітальних округів відповідає стратегії децентралізації влади в Україні та ґрунтується на принципі доцільності, закладеної в концепцію госпітальних округів. Основою створення госпітального округу $є$ доступність населення до медичної допомоги. Окрім того, медичний заклад має бути забезпечений безперервним потоком пацієнтів, щоб лікар мав підтримку своїх професійних фахових (с) О. Н. Литвинова, Р. А. Демус, 2017 навичок, а також з міркувань раціонального використання коштів.

Створення госпітальних округів визначено Основами законодавства України про охорону здоров'я (Закон України від 19.11.1992 р. № 2801-XII, стаття 35-2) [1]. Старт медичній реформі дала прийнята Урядом України Концепція реформи фінансування системи охорони здоров'я (розпорядження Кабінету Міністрів України від 30.11.2016 р. № 1013-р.), яка започатковує поступовий (до 2020 р.) перехід на нову модель фінансування галузі (національного солідарного медичного страхування), що охоплюватиме все населення [2].

3 моменту затвердження Кабінетом Міністрів України у листопаді 2016 р. Порядку створення госпітальних округів (Постанова Кабінету Міністрів України від 30.11.2016 р. № 932) по всій території України розпочався процес створення госпітальних округів [3]. Згідно із зазначеною Постановою, «госпітальний округ - це функціональне об'єднання закладів охорони здоров'я, розміщених на відповідній території, що забезпечує надання вторинної (спеціалізованої) медичної допомоги та екстреної медичної допомоги населенню цієї території». 
На виконання вищезазначеної Постанови наказом Міністерства охорони здоров'я України від 20.02.2017 р. № 165 затверджено Примірне положення про госпітальний округ [4]. Створення таких округів має на меті, з одного боку, гарантувати пацієнтам своєчасність доступу до медичної допомоги, а з іншого - забезпечити максимально можливу якість медичної допомоги за умови раціонального та ощадливого використання бюджетних коштів.

До складу госпітального округу мають входити не менше однієї багатопрофільної лікарні інтенсивного лікування першого та (або) другого рівня та інші заклади охорони здоров'я. Центром госпітального округу визначають населений пункт (що географічно $\epsilon$ найближчим до центру округу), як правило, місто з населенням понад 40 тис. осіб, в якому розміщена багатопрофільна лікарня інтенсивного лікування другого рівня.

На сьогодні, коли реформа системи охорони здоров'я набирає обертів, питання ролі медичної сестри та її професійного місця є особливо вразливим питанням, позаяк все частіше спостерігаємо масовий виїзд професійних медсестер за кордон.

Для відповіді на питання про роль та місце медсестри за умов реформування системи охорони здоров'я та створення госпітальних округів зокрема, ми вважали за доцільне насамперед вивчити формування госпітальних округів в Івано-Франківській області [5], дослідити стратегію розвитку мережі закладів охорони здоров'я в госпітальних округах, окреслити перспективи перепрофілізації закладів охорони здоров'я в цих госпітальних округах, визначити стратегічні потреби середнього медичного персоналу в закладах охорони здоров'я та функціональні обов'язки головної медсестри за умов створення госпітальних округів. Також вважаємо важливим провести порівняльну характеристику функціональних обов'язків головної медсестри в закладах охорони здоров'я до адміністративної реформи і в умовах госпітальних округів. Такі дані дозволять сформувати нові компетенції головної медсестри, необхідні їй для роботи в умовах госпітальних округів, що можна буде використати за умов підготовки медичних сестер.

Висновки. Питання місця медсестри в структурі госпітальних округів $є$ надзвичайно актуальним. У зв'язку із чим проведена робота допоможе удосконалити систему формування функціональних обов'язків медсестри за умов створення госпітальних округів на рівні окремого закладу охорони здоров'я та рівні госпітального округу загалом.

\section{СПИСОК ЛІТЕРАТУРИ}

1. Основи законодавства України про охорону здоров'я : Закон України від 19.11.1992 р. № 2801-XII, стаття 35-2 [Електронний ресурс]. - Режим доступу : http://zakon2. rada.gov.ua/laws/show/2801-12

2. Концепція реформи фінансування системи охорони здоров'я : розпорядження Кабінету Міністрів України від 30.11.2016 р. №1013-р. [Електронний ресурс]. - Режим доступу : http://zakon2.rada.gov.ua/laws/show/1013-2016$\% \mathrm{D} 1 \% 80$

3. Про порядок створення госпітальних округів : Постанова Кабінету Міністрів України від 30.11.2016 р. № 932 [Електронний ресурс]. - Режим доступу : https://

xn--80aagahqwyibe8an.com/ministriv-kabineta-postanovi/ postanova-vid-listopada-2016-932-pro-2016-46925.html

4. Примірне положення про госпітальний округ : наказ Міністерства охорони здоров'я України від 20.02.2017 р. № 165 [Електронний ресурс]. - Режим доступу : http://moz. gov.ua/ua/portal/dn_20170220_165.html

5. Кабмін затвердив перелік та склад госпітальних округів на Івано-Франківщині [Електронний ресурс] / Місто. - 2017. - 15 липня - Режим доступу : http:// mi100.info/2017/07/15/kabmin-zatverdyv-perelik-ta-skladgospitalnyh-okrugiv-na-ivano-frankivshhyni/ 